\title{
Gastrointestinal stromal tumor - an evolving concept
}

\author{
Luigi Tornillo* \\ Institute of Pathology, University of Basel, Basel, Switzerland
}

\section{Edited by:}

Dolores Di Vizio, Harvard Medical

School, USA

\section{Reviewed by:}

Rosa Marina Melillo, University of Naples Federico II, Italy

Renato Franco, Istituto Tumori

Fondazione Giovanni Pascale, Italy

${ }^{*}$ Correspondence:

Luigi Tornillo, Institute of Pathology,

University of Basel, Schönbeinstrasse

40, CH-4003 Basel, Switzerland

e-mail: tornillol@uhbs.ch
Gastrointestinal stromal tumors (GISTs) are the most frequent mesenchymal tumors of the gastrointestinal tract. The discovery that these tumors, formerly thought of smooth muscle origin, are indeed better characterized by specific activating mutation in genes coding for the receptor tyrosine kinases (RTKs) CKIT and PDGFRA and that these mutations are strongly predictive for the response to targeted therapy with RTK inhibitors has made GISTs the typical example of the integration of basic molecular knowledge in the daily clinical activity. The information on the mutational status of these tumors is essential to predict (and subsequently to plan) the therapy. As resistant cases are frequently wild type, other possible oncogenic events, defining other "entities," have been discovered (e.g., succinil dehydrogenase mutation/dysregulation, insuline growth factor expression, and mutations in the RAS-RAF-MAPK pathway). The classification of disease must nowadays rely on the integration of the clinico-morphological characteristics with the molecular data.

Keywords: gastrointestinal stromal tumors, gastrointestinal tract, CKIT, targeted therapy, receptor tyrosine kinase

\section{INTRODUCTION}

Gastrointestinal stromal tumors (GISTs) are the most frequent mesenchymal tumors of the gastrointestinal tract, with an incidence between 15 and 20 new cases/10,00,000/year $(1,2)$. The actual incidence may be, however, higher, as incidental GISTs are relatively frequent (3-6). The most frequent localization is the stomach, followed by the small intestine, the colon-rectum, and the esophagus (7). The existence of true extragastrointestinal GISTs is controversial. Although the concept that mesenchymal tumors of the gastrointestinal tract with leiomyomatous morphology are "bizarre" or "blastomatous" had been established almost 70 years ago by Stout $(8,9)$, the actual histogenesis of these tumors was defined about 30 years ago (in the pre-immunohistochemistry era) by Mazur and Clark (10), who proposed the non-committal term of "Gastrointestinal stromal tumors." With the development of immunohistochemistry, the concept could be better specified. Most cases (70\%) were positive for CD34, and the expression of smooth muscle markers was seen in less than $50 \%$. CD34 is normally expressed in endothelia, in hematopoietic stem cells, perivascular fibroblasts, and stromal fibroblasts in various localization, thus underlining the "stromal," but uncommittal nature of these tumors (11). Moreover, CD34 is expressed in a proportion of interstitial cells of Cajal (ICC), the pacemaker cells of the gastrointestinal tract $(12)$. In 1998, two groups $(13,14)$ showed independently that more than $80 \%$ of these enigmatic tumors harbor constitutively activating mutations of the $c k i t$ gene that encode an important receptor tyrosine kinase (RTK) type III. CKIT (also known as CD117) immunohistochemical expression was contemporarily reported in more than $95 \%$ of GIST cases, thus becoming an important tool for the diagnosis $(15,16)$ (Figure 1). The immunophenotype is shared by the ICC (17), so that Kindblom et al. proposed in their paper the term "GIPACT," GastroIntestinal PAcemaker Cells Tumor. This term was, however, not retained. Although sometimes questioned, the theory of origin from ICC is nowadays generally accepted. In 2003, it was shown that a substantial fraction of CKIT-wild-type GISTs' harbor-activating mutations in pdfgra (platelet-derived growth factor alpha) gene, coding for another important RTK type III (18). This confirms that the oncogenesis of GISTs is probably related to early activation of RTKs. Interestingly, the immunohistochemical positivity for CD117 is independent from the mutational status of RTK genes (19). Another almost pathognomonic IHC marker is DOG-1, corresponding to the potassium transporter ANO1 (Figure 1D). The importance of the RTK mutational status is also underlined by the fact that CKIT and PDGFRA are very good target for the targeted therapy with the RTK inhibitor imatinib mesylate (Gleevec ${ }^{\circledR}$, Novartis Pharma AG, Basel, Switzerland). Imatinib is now the firstline option in the medical treatment of GISTs $(1,20)$. Imatinib is approved in US and in Europe for adjuvant therapy (21) and may be used also in a neoadjuvant setting to reduce the tumor mass (1). Imatinib is very effective on sensitive GISTs as it was shown in the communication of Joensuu published in "The New England Journal of Medicine" in 2003 (22).

The therapy with imatinib has become the paradigm of targeted therapy in solid tumors. In spite of this great success, primary and secondary resistance to targeted therapy remains a problem to solve. Beneath a minority of GISTs that simply do not respond to the therapy with imatinib (primary resistance), due probably to their genetic constitution (see below), half of the patients develop disease progression after 2 years of treatment with imatinib (23). The main predictor of the response to therapy is represented by the mutation in the RTK genes $(7,21,24)$. The genetic alterations in the RTK genes are important early events in the oncogenesis of GISTs, and define the response to targeted therapy.

Recently, mutations in BRAF and KRAS, both belonging to the RAS-RAF-MAPK pathway $(25,26)$, and hyperexpression of the transcription factor ETV1 (27) have been described.

The understanding of GISTs biology has stimulated the development of RTK inhibitors. Nowadays, there are at least three molecules that can be used against KIT and/or PDGFRA. The 

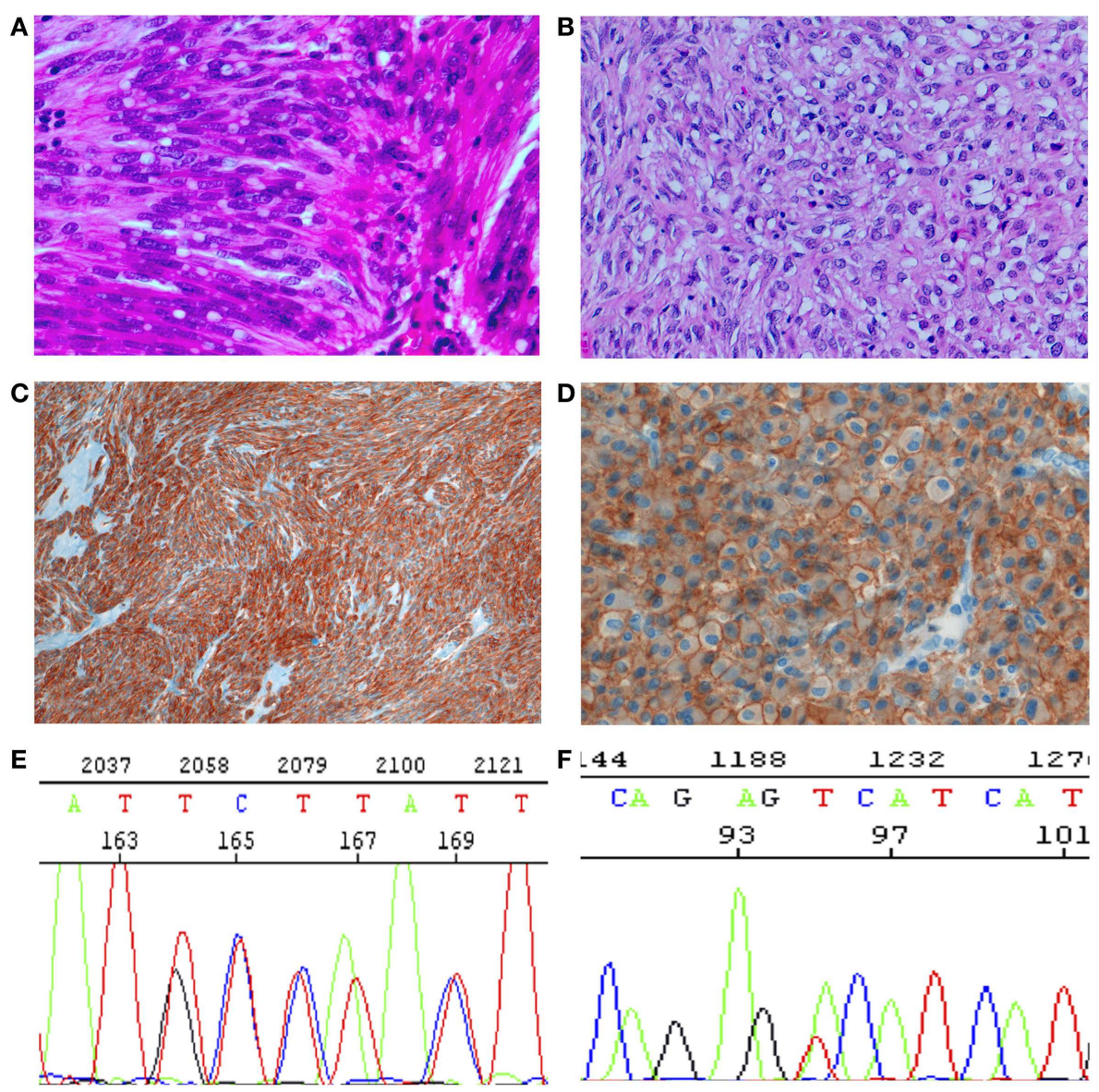

FIGURE 1 | Histology, immunohistochemistry, and molecular genetics of GISTs. (A,B) Histology. (A) Spindle cell tumor, with paranuclear vacuoles (so-called "leiomyoblastoma"). HE 40×. (B) Epitheloid tumor. Large, clear cytoplasm with central nucleus. HE 40x. (C) Spindle cells diffusely positive for CKIT (CD117). IHC 10×. (D) Epitheloid cells strongly and diffusely positive for DOG1, with evident membrane enhancement. $I H C 40 \times$. (E) Sanger sequencing with a duplication of GCC TAT in positions 502-503 (p.A502-Y503 dup). Mutation associated with sensitivity to imatinib. (F). Sanger sequencing with a substitution (A-C) in position 842, (p.D842V), imatinib resistant. evolution of the idea of GISTs represents also how our paradigm of classification of disease is changing. From a "morphologic/etiologic" classification, we are going to more dynamic and flexible criteria, where the "old" clinicopathologic parameters are integrated with/substituted by the molecular alterations. This process is advancing also in other fields of oncology, as shown e.g., by the fourth edition of the WHO/IARC "blue books" (http://www.iarc.fr/en/research-groups/sec4/).

This review will, therefore, focus on the biology and molecular pathology of GISTs, and on the evolution of their classification.

\section{MOLECULAR ALTERATIONS IN GISTS \\ RTK III}

CKIT and PDGFRA are RTK III, together with PDGFRB, macrophage colony-stimulating-factor receptor (CSFR1), FLT1, Flk/KDR, and Fl cytokine receptor (FLT3) $(28,29)$. RTK III have five Ig-like extracellular domains, one transmembrane domain, one intracellular juxtamembrane regulatory domain, and two intracellular tyrosine kinase domain with autophosphorylating capacity (29) (Figure 2). CKIT and PDGFRA are located on the same chromosomal region $(4 \mathrm{q} 12)$ and are very similar, both in the sequence and in the structure (29). The ligands (stem cell factor, SCF for CKIT and platelet-derived growth factor, PDGF for PDGFRA) cause homodymerization of the receptor. Subsequently, the TK domains autophosphorylate and activate, triggering the metabolic pathways of RAS-RAF-MAPK, PI3K-AKT, and signal transducer and activator of transcription 3 (STAT3) (30-34).

\section{CKIT}

CKIT is crucial in the development of different cell types, in particular melanocytes, hematopoietic progenitor cells, mast cells, primordial germ cells, and, last but not least ICC, the probable cells of origin of GISTs $(17,21,35)$. KIT-activating mutations are important for the genesis and development of several human tumor types: seminoma/dysgerminoma, mastocytosis, acute myeloid leukemia, melanoma, and GIST (36-39). CKIT can be, therefore, considered as an important oncogenetic factor in various different tissues.

Germline KIT mutations are very rare and they are associated with familial GISTs (21), while activating mutations are generally 


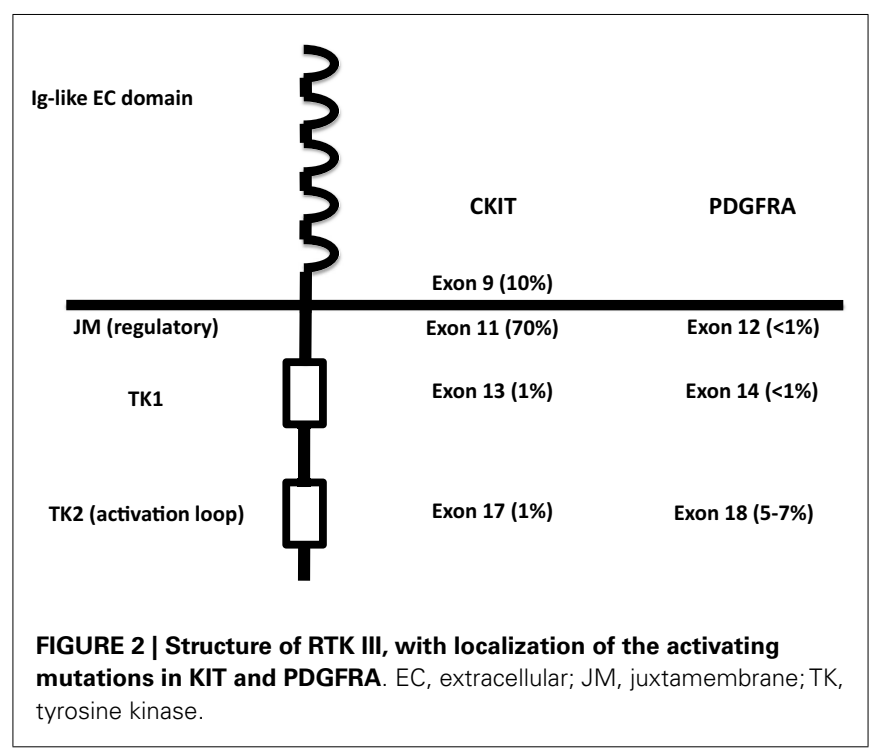

somatic and cause homodymerization of KIT and subsequent tyrosine kinase activation without SCF binding. Activating mutations are most frequently (60-70\% of cases) found in exon 11 of CKIT gene (7), corresponding to the juxtamembrane intracellular regulatory domain of the protein (Figure 2). Because of exon 11 mutations, the protein changes its structure from the inactive into the active state (40). There are many different mutation types (in-frame deletions, insertions, substitutions) in various combinations $(24,29,41)$. The kind of the alteration is clearly associated with clinicopathologic characteristics, such as prognosis and localization. For instance, deletions, of codons 557-558, are associated with shorter overall and disease-free survival (42-45), whereas tandem internal duplications (Figure 1E) are associated with a relatively indolent course $(46,47)$.

Exon 9 (corresponding to the extracellular domain of the KIT molecule) mutations are present in almost $10 \%$ of GIST cases $(7,48)$ and are almost only duplications of six nucleotides, corresponding to the A502_Y503 residues of the protein (49). The mutations probably induce conformational changes similar to SCF binding, leading to autoactivation. Exon 9-mutated GISTs are more often localized in small intestine or colon and have poorer prognosis (47-53). They have also different gene expression signatures (50).

Mutations in tyrosine kinase domain (exon 17) and ATPbinding site (exon 13) are rare and generally not primary $(7,34$, $42,51-60)$. They are generally secondary mutations arising during the targeted treatment with receptor tyrosine kinase inhibitors (RTKI), and induce secondary resistance (58-60) (see below). Most KIT exon 13 mutations are single substitutions leading to $\mathrm{K} 642 \mathrm{E}$ in the aminoacidic sequence (52).

Recently, deletion of codon 419 in exon 8 of KIT (corresponding to the extracellular domain) have been described in a very small subset of GIST $(\approx 0.2 \%$ of all cases) $(61)$. This mutation was found also in systemic mastocytosis. Interestingly, it seems that this mutation is associated with sensitivity to RTKI.

Activating mutations of KIT trigger pathways, such as MAPK, PI3K-AKT, and STAT3 $(30,33,62-66)$. The MAPK pathway is functionally related to several transcription factors (e.g., MYC, ELK, and CREB) and finally positively controls the cell cycle (67). The PI3K pathway, through phosphorylation of AKT and PDK1, acts against the apoptosis and indirectly stimulates the cell cycle (68). Phosphorylation of STAT3 triggers its transport in the nucleus and behaviors as a transcription factor, with a positive effect on proliferation and a negative effect on apoptosis (69).

Activation of RTK is surely pivotal in the oncogenetic pathway of GISTs, and represents an early event, but is not the exclusive factor for the acquisition of the transformed phenotype. For instance, a very interesting and elegant study has been published (27), suggesting that ETV1 (ETS translocation variant 1) may interact with KIT in the oncogenesis. The clinical importance of ETV1, however, is controversial $(70,71)$.

Proteasome degradation regulates physiological levels of KIT. Mutated KIT is degraded more slowly than wild-type KIT, probably because of physical interaction with heat-shock protein 90 (72, 73). HSP90 inhibitors are indeed effective in experimental models of GISTs (74).

\section{PDGFRA}

PDGFRA has similar sequence and function as KIT. It is mutated in GISTs and AML and translocated on FILP1 in hematologic malignancies (21). Activating mutations in KIT and PDGFRA are mutually exclusive in GISTs $(18,31)$. Mutations in PDGFRA are in exons 12,14 , and 18, corresponding to the juxtamembrane regulatory domain and the tyrosine kinase domain of the protein, respectively (exons 11, 13, and 17 of KIT). PDGFRA-mutated GISTs are $10-12 \%$ of all cases $(53,56,57,75-79)$. They have epitheloid morphology and are generally gastric tumors, showing an indolent course (80-82). They also have different gene expression signatures $(32,83)$. On the other hand, the immunohistochemical phenotype (positivity for CD117, DOG-1, and PKC-Theta), the chromosomal alteration (deletion of $14 \mathrm{q}$ and $22 \mathrm{q}$ ), and the biochemical properties (activated pathways and stabilization by HSP90) of PDGFRA-mutated GISTs overlap with CKIT-mutated tumors (84-87). The most frequent mutations in PDGFRA involve the aspartic acid in position 842 (Figure 1F) and are generally not sensitive to imatinib $(18,79,88-95)$. Insertions and duplications are very rare, while deletions and deletions/insertions between codon 840 and 849 are more frequent. In exon 12, the most frequent mutation is a substitution $\mathrm{T}->\mathrm{A}$, leading to a Val561Asp (19). In-frame deletions are also relatively frequent in exon 12, clustering in codons 559-72. Mutations in exon 14 are exceptional.

\section{RAS-RAF-MAPK PATHWAY}

In all, $10-15 \%$ of GISTs are wild type both for KIT and PDGFRA. This genotype is not related to the immunophenotype, namely with the positivity to KIT (CD117) and DOG1 stainings. Several "wt"-GISTs are strongly positive for CKIT (CD117), and the involvement of RTK has been proved functionally (phosphorylation and subsequent activation) (30). These so-called "wild-type" GISTs are a very heterogeneous group, showing different, probably oncogenic mutations. BRAF V600E has been described in 13\% of "wild-type" GISTs $(25,58,96)$. At the beginning, it was thought that the BRAF mutations were characteristic of "wild-type" GISTs. In a recent study, Miranda et al. (26) have suggested that BRAF 
is mutated in ca., 2\% of GISTs carrying KIT or PDGFRA mutation, thus suggesting a further mechanism of primary resistance to imatinib treatment (see below). In the same study, 5\% of GISTs carrying mutations in KIT or PDGFRA showed mutation in codon 2 of KRAS (G12A or G13D). Also, mutations in HRAS and NRAS have been found, but they are very rare. The presence and, above all, the meaning of mutations in KRAS were questioned by a recent study on 450 GISTs sequenced with Sanger's method (97).

\section{NEUROFIBROMATOSIS 1}

Neurofibromatosis 1 (NF1) (von Recklinghausen disease) is an autosomal dominant inherited disease, characterized by multiple neurofibromas, café-au-lait spots, and other mesenchymal tumors. NF1 is caused by inactivating mutations in the gene NF1, localized on chromosome 17, coding for neurofibromin (98). Patients with NF1 have an increased risk to develop multiple GISTs, with a spindle cell morphology and with predominant intestinal location (99). The tumors have rarely, "uncommon" mutations in RTK, but CKIT and PDGFRA most often are not mutated (100-104). Neurofibromin is analog to guanosine triphosphatase (GTPase) activating proteins (GAPs), which control the level and activity of RAS. Loss of NF1 leads to high levels of active RAS. Hyperactivation of the MAPK pathway is a consequence of somatic inactivation of wild-type NF1 allele in GISTs (105). From the cytogenetic point of view, they share deletion of $14 \mathrm{q}$ and $22 \mathrm{q}$ with classical GISTs.

\section{SUCCINATE DEHYDROGENASE COMPLEX}

Succinate dehydrogenase complex $(\mathrm{SDH})$ is a heterotetramer composed by four subunits (SDHA-D), localized in the inner mitochondrial membrane. Subunit A oxidizes succinate to fumarate in the Krebs' cycle. Subunit B participates in the electron transport chain for the oxidation of ubiquinone to ubiquinol, and subunits $\mathrm{C}$ and D (SDHC and SDHD) are membrane-anchoring subunits (106). SDH deficiency characterizes subsets of different tumors (e.g., GISTs, paragangliomas, renal cell carcinomas, and pituitary adenomas) $(107,108)$. SDH-deficient GISTs (identified by immunohistochemical negativity for SDHB) are the largest subgroup of "wt-GIST" (109, 110). They are always found in the stomach, are epitheloid, and often multiple and resistant to imatinib. Moreover, in contrast to "classical" GISTs, they metastasize to lymph nodes, and show activation of insuline growth factor receptor (IGFR). Their prognosis is not determined only by size, site, and mitotic index (110-116). They have an indolent course and even with liver metastases, the patients live long. SDHdeficient GISTs are the majority of pediatric GISTs in the stomach (110) and are part of two syndromes: the Carney triad (association of paranganglioma, pulmonary chondroma, and gastric GIST) and the Carney-Stratakis syndrome (association of GISTs and paragangliomas) $(113,117)$. The genetic events involved in the tumorigenesis of these tumors are not yet completely clarified $(118,119)$ and, in half of them, no mutation has been identified, although the IHC staining for SDH is negative (120). Defects of SDHx (independent from the involved subunit) induce accumulation of succinate, which inhibits degradation of HIF, subsequent increase of HIF levels, and its translocation in the nucleus, where HIF triggers the transcription of VEGF and IGF1R (121,
122), with aberrant proliferation and tumorigenic responses. A review of more than 1000 GISTs has shown that IGF1R expression is preferentially expressed in gastric SDH-deficient GISTs, but never in intestinal GISTs (123). The role of the axis IGF-IGF1R in maintaining the proliferative activity in GISTs has also been confirmed, both experimentally and on a series of SDH-deficient GISTs $(124,125)$.

\section{CHROMOSOMAL ALTERATIONS}

Chromosomal losses are much more frequent than chromosomal gains in GISTs. Losses of $14 q, 22 q$, and $1 p$ are the most frequent losses (126-128) and may subclassify GISTs in subsets with specific characteristics (129). Other losses are $-9 \mathrm{p},-11 \mathrm{p},-17 \mathrm{p}$, $-10 q,-13 q$, and $-15 q$. Combining array CGH and transcriptome analysis Ylpaa et al. (130) have shown that the accumulation of cytogenetic changes (chromosomal losses) parallels the evolution of the tumor and could be seen as "genetic staging." Specific genes (e.g., OXA1L on 14q and AKAP13 on 15q) are differentially expressed in the different "genetic stages."

Cytogenetic gains are relatively rare and localized, but are associated with malignancy. In particular, gains on the loci for CCND1 and MDM2 gains have been shown to be associated with malignancy (131). On the other hand, genes involved in cell cycle control are dysregulated in high-risk tumors. Deletion or epigenetic inactivation of the gene CDKN2A, encoding for p16 and p14, two regulators of the cell cycle, is associated with malignant behavior (132-134). p16 downregulation may cause through Rb phosphorylation E2F1-dependent transcription of genes essential for late G1/S phase transition (135).

\section{TARGETED THERAPY}

The prognosis of high-risk/advanced GISTs has been very poor until 2000. Surgery was the exclusive therapy, and the median survival was less than 18 months (136). The introduction of imatinib mesylate in the therapy changed dramatically this situation. Imatinib was originally developed for chronic myeloid leukemia (CML) (29). It has a very strong inhibitory activity against KIT, fixing it in its inactive conformation. After the first communication of the dramatic success of the therapy in a case of advanced metastatic GIST in a 50-year-old woman (22), it was rapidly introduced in the therapy of metastatic non-resectable tumors and is now approved also in the adjuvant setting, with a clear-cut improving of the median survival ( 5 years). The most important predictive factor of the response to targeted therapy is the mutational status of the RTK genes $(19,21,97)$. The best response rate is achieved with mutations in exon 11 of CKIT gene that are generally associated with a high response rate $(\approx 80 \%)$, whereas mutations in exon 9 are associated with a response rate of $\approx 45 \%$ $(91,137)$ and deserve a higher doses of RTKI (Table 1). Mutations in exon 13 and exon 17 of CKIT are generally not responsive, such as mutations in codon 842 of PDFGRA and wt-GISTs (see below).

In the attempt to achieve a better response to therapy, many other different RTKI are in use or on trial. The best results have been achieved with sunitib and regorafenib that are at present used as second- and third-line treatments (138). A summary of the possible targets and targeted drugs is shown in Figure 3. 
Table 1 | Integration between clinicopathologic and molecular criteria in the classification of GISTs.

\begin{tabular}{|c|c|c|c|c|c|c|c|c|}
\hline Genetic alteration & Mutation & Frequency & Localization & Histology & Prognosis & Imatinib resp. & Syndromes & Remarks \\
\hline \multicolumn{9}{|c|}{ KIT-MUTATED ( $\approx 70 \%)$} \\
\hline Exon 9 (EC) & Insertion AY502-503 & $\approx 10 \%$ & $\begin{array}{l}\text { Small bowel } \\
\text { and colon }\end{array}$ & Spindle cell & Poorer & $\begin{array}{l}\text { Partially resistant } \\
(\approx 45 \% \mathrm{RR})\end{array}$ & None & $\begin{array}{l}\text { Higher dose requested; } \\
\text { sunitinib }\end{array}$ \\
\hline \multirow[t]{3}{*}{ Exon 11 (JM) } & $\begin{array}{l}\text { W557-K558del } \\
\text { Deletion } \\
\text { Deletion-Insertions }\end{array}$ & $\approx 70 \%$ & Whole GI tract & $\begin{array}{l}\text { Spindle cell or } \\
\text { epithelioid cell }\end{array}$ & Poorer in stomach & $\begin{array}{l}\text { Generally } \\
\text { responsive } \\
(\approx 80 \% \mathrm{RR})\end{array}$ & $\begin{array}{l}\text { Many different } \\
\text { familial GIST } \\
\text { syndromes }\end{array}$ & \\
\hline & Substitutions & & & & Better in stomach & & & \\
\hline & Duplications & & $\begin{array}{l}\text { Generally } \\
\text { stomach }\end{array}$ & Spindle cell & Better in stomach & & & \\
\hline \multirow[t]{3}{*}{ Exon 13 (TK) } & K642E & $1 \%$ & Whole GI Tract & & Poorer in stomach & Responsive & & \\
\hline & V654A & & & & Poorer & Resistant & & $\begin{array}{l}\text { Causes secondary } \\
\text { resistance }\end{array}$ \\
\hline & T670I & & & & Poorer & Resistant & & $\begin{array}{l}\text { "Gatekeeper." } \\
\text { Secondary resistance }\end{array}$ \\
\hline $\begin{array}{l}\text { Exon } 17 \\
\text { (activation loop) }\end{array}$ & $\begin{array}{l}\text { Substitutions (D816, D820, } \\
\text { N822) }\end{array}$ & $0.5-1 \%$ & Whole GI tract & & $\begin{array}{l}\text { No prognostic } \\
\text { value }\end{array}$ & Resistant & & Secondary resistance \\
\hline \multicolumn{9}{|c|}{ PDGFRA-MUTATED ( $\approx 7 \%)$} \\
\hline Exon 12 (JM) & $\begin{array}{l}\text { Deletions/substitutions (e.g., } \\
\text { V561D) }\end{array}$ & $\approx 1 \%$ & Stomach & $\begin{array}{l}\text { Epithelioid or } \\
\text { mixed spindle } \\
\text { cell/epithelioid }\end{array}$ & Indolent course & Responsive & $\begin{array}{l}\text { Familial GIST } \\
\text { syndromes }\end{array}$ & \\
\hline $\begin{array}{l}\text { Exon } 14 \text { (TK } \\
\text { domain) }\end{array}$ & N659K, N659I & $<1 \%$ & & & & Responsive & None & \\
\hline Exon 18 & D842V, D842Y & $\approx 5 \%$ & & & & Resistant & Familial GISTs & \\
\hline \multirow[t]{2}{*}{ (activation loop) } & Other substitutions & $<1 \%$ & & & & Responsive & None & \\
\hline & $\begin{array}{l}\text { Deletions: 1843, I843-H845, } \\
\text { D842-H845, D842-M844 }\end{array}$ & $1 \%$ & All GI tract & & & Responsive & Familial GISTs & \\
\hline
\end{tabular}




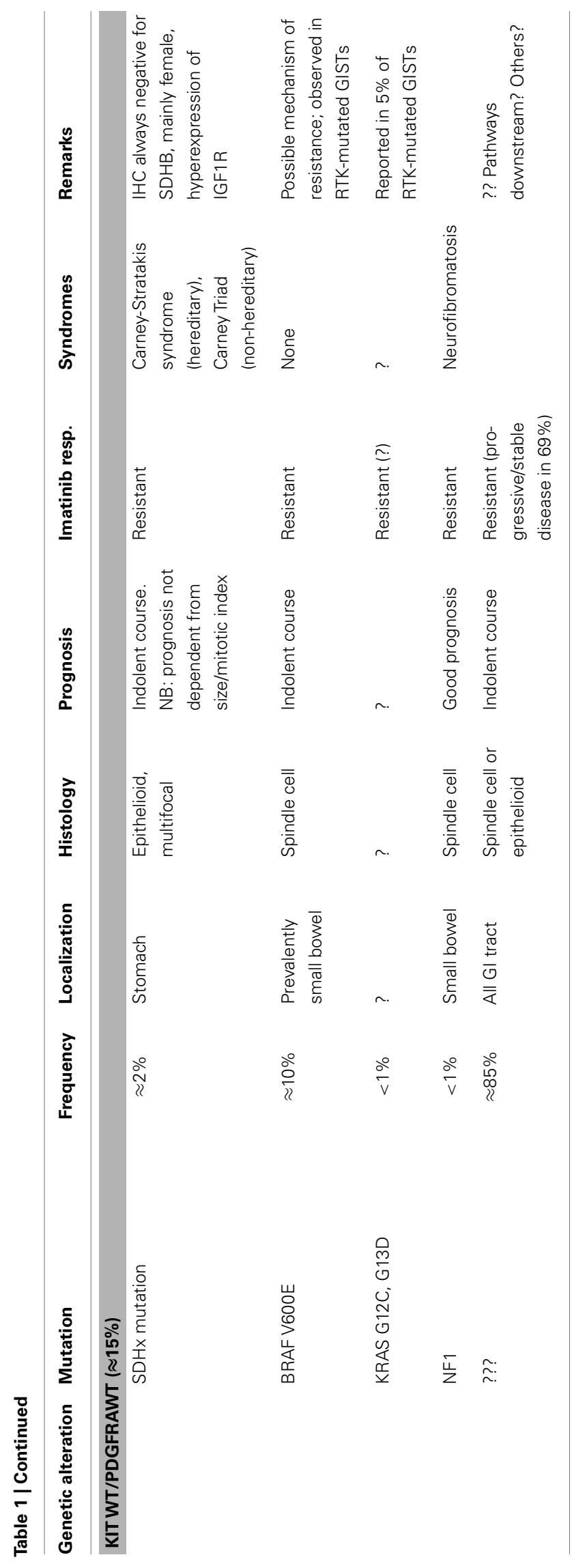

\section{RESISTANCE TO THERAPY}

In spite of the dramatic success of the targeted therapy with RTKI, there is evidence that also long-life imatinib treatment does not destroy completely GIST cells $(139,140)$ and that resistance to TKI therapy, both primary and secondary, arises in most of the cases (141).

\section{PRIMARY RESISTANCE}

Progression within the first 6 months of treatment with imatinib means primary resistance. The only predictor of primary resistance is the mutation in RTK (CKIT and PDGFRA) genes (29, 141 ). The probability of primary resistance is $5 \%$ for mutations in exon 11 of KIT, $16 \%$ for mutations in exon 9 of KIT, and $23 \%$ for wild-type GIST $(59,142)$. Tumors with mutation in exon 9 need a higher daily dose (800 mg instead of $400 \mathrm{mg}$ ) (29). Other CKIT mutations (EC domain, TK domain, or activation loop, exons 8 , 13, and 17) of KIT are rare and mostly associated with resistance, although in some cases a response has been reported (e.g., K642E) $(61,143)$. PDGFRA D842V mutation in the exon 18 is strongly resistant to imatinib therapy, while other mutations in PDGFRA are usually sensitive $(91,141,144)$. The mechanisms of primary resistance in "wild-type" KIT are probably multiple and not yet clarified. One possibility is represented by alterations in molecules "downstream" RTK, such as BRAF and KRAS, as hypothesized by Miranda et al. (26). In NF1-related GISTs, that are resistant to imatinib therapy, the activation of the MAPK-ERK axis due to silencing of the NF1 gene (see above) is probably the chief factor for imatinib resistance (105). For pediatric or SDH-mutated GISTs, that are almost invariably wild type for RTK, other possible targets may be KDR (VEGFR) or mTOR $(41,109)$.

\section{SECONDARY RESISTANCE}

As recalled above, $50 \%$ of the patients treated with imatinib relapse after 2 years (23). It is interesting to note that progression is sometimes marked by an increase in density, with or without an increase in size. A sign of progression may also be the occurrence of an area of CT-hyperdensity within a responding (hypodense) lesion. This gives rise to the so-called "nodule within the nodule" pattern (141). This underlines the need of a revision of the classical oncologic criteria for progression (145). Secondary mutations in KIT or PDGFRA genes are the cause of most of the cases of secondary resistance $(23,142,146-148)$. They generally occur in the same gene of the primary mutation. In KIT, they are localized in exon 13 or 17 of KIT, corresponding to the ATP-binding pocket and to the activation loop, respectively, the most frequent being T607I in the ATP-binding pocket (exon 13), followed by V654A (exon 13) and T823D (exon 17) $(60,137,149)$. In most cases, the secondary mutation in PDGFRA is D842V. It is important to note that in case of relapse constituted by multiple nodes, these are often multiclonal, with different mutations in different nodes $(23,60,142$, 150). This molecular heterogeneity can also explain the relatively low efficacy of targeted therapy against relapsing GISTs.

\section{OTHER MECHANISMS OF RESISTANCE}

Amplification of KIT or PDGFRA gene has been implicated in the development of resistance in RTK-wild-type GISTs (151). Activation of alternate oncogenic pathways is another possible 


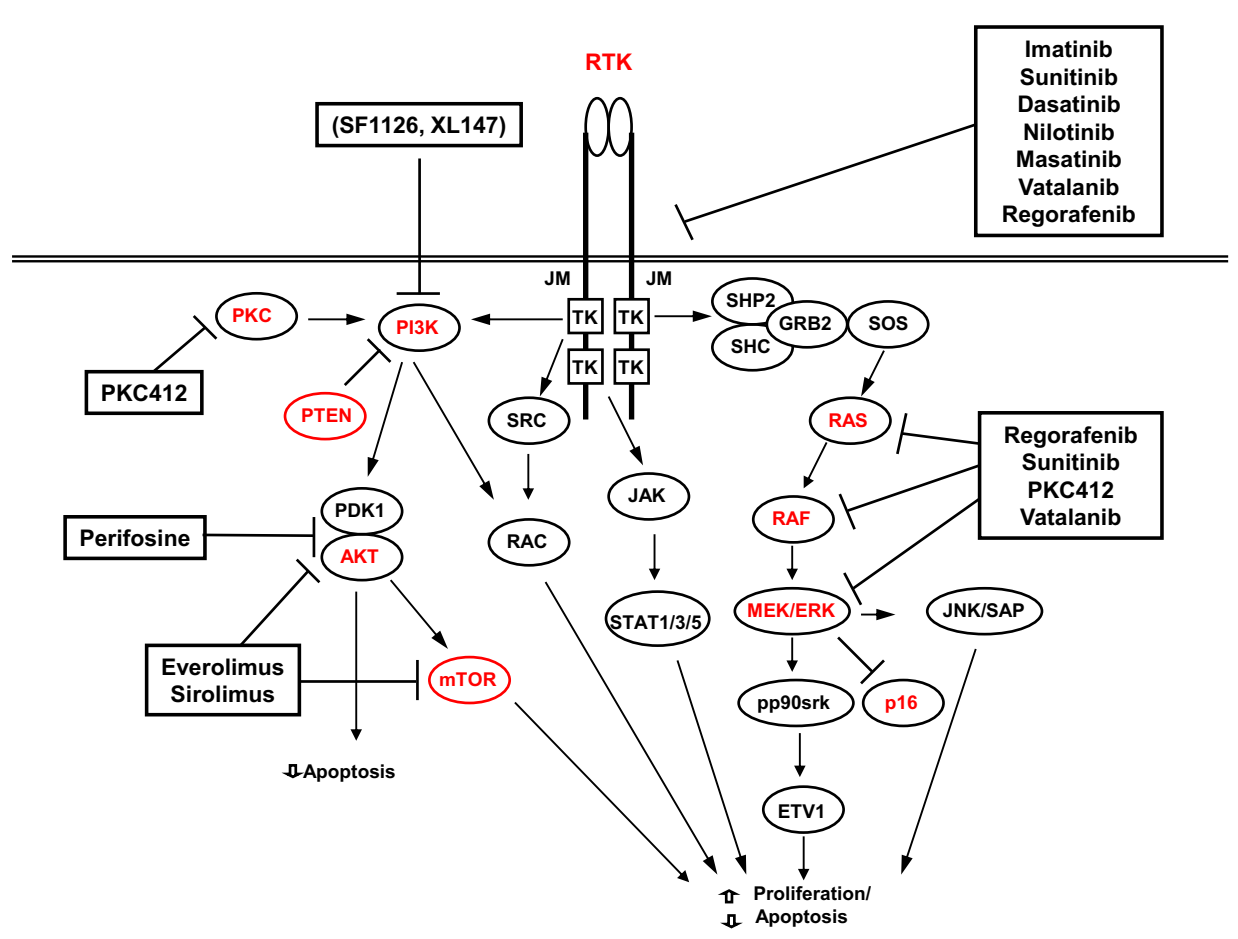

FIGURE 3 | Possible therapeutic targets (red) and targeted drugs in GISTs.

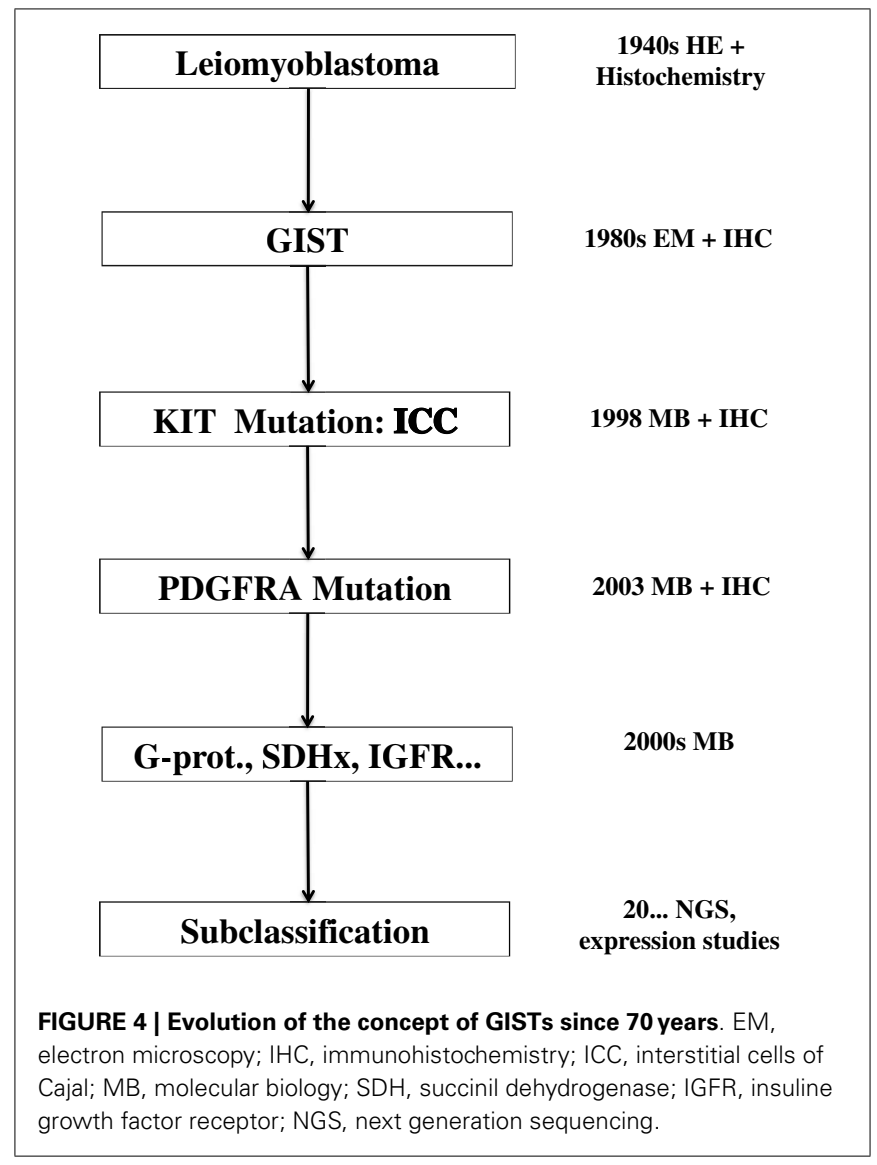

resistance mechanism. This is the case of KRAS and BRAF (26) or PI3K/AKT pathway upstream of mTOR (152). IGF1R may represent another mechanism of resistance. It is expressed in subsets of RTK wild-type GISTs $(58,153)$. IGF1R-targeted therapy of wild-type GIST is being investigated in clinical trials (e.g., NCT01560260) (154).

These possible alternate mechanisms of resistance (primary or secondary) underline the necessity to develop schemes of therapy with a broad mechanism of action. Besides inhibitors combination and inhibitors with a broad spectrum (sorafenib, masitinib, vatalanib, nilotinib, or dasatinib that target also the VEGFR1 and VEGFR2), an important possibility is, therefore, aiming at other pathways. Promising targets are HSPs, histone deacetylases, signaling intermediates, or pathways, such as mTOR, PI3K, or MAPK [for review, see Ref. (138)].

\section{CONCLUSION}

The tremendous impact of molecular biology on modern medicine cannot be overestimated. In my opinion, the most important issue is the change of the paradigm of classification. GISTs represent a diagnostic category that changes its meaning and becomes more complex in parallel to the development of diagnostic tools and therapy (Figure 4). The non-committal term "GIST" probably, covers different "entities" (e.g., pediatric GISTs or SDH-deficient GISTs). A philosophical discussion on the actual meaning of the word "entity" in pathology and medicine goes beyond the purpose of this review. I think, however, that "entity" is an operative concept, whose content depends and is modified on the basis of the available diagnostic and therapeutic tools. This can be seen 
clearly in the case of GISTs. From the notion of a leiomyomatous tumor, based on HE staining, we are now dealing with a definition/classification that relies mainly on IHC stainings and molecular techniques, whereas the latter are essential for defining prognostic and therapeutic categories. The therapeutic strategy is the most important criterium for a medical classification, since the aim of medicine is the care of the patient. On the other hand, the behavior of GISTs can be defined only by integrating the molecular genetic findings with the "classical" clinicopathological parameter. A modern disease classification must, therefore, rely on the combination/integration of morphology and molecular biology (Table 1).

\section{REFERENCES}

1. Demetri GD, von Mehren M, Antonescu CR, DeMatteo RP, Ganjoo KN, Maki RG, et al. NCCN Task Force Report: update on the management of patients with gastrointestinal stromal tumors. J Natl Compr Canc Netw (2010) 8(Suppl 2):S1-41.

2. Nilsson B, Bumming P, Meis-Kindblom JM, Oden A, Dortok A, Gustavsson B, et al. Gastrointestinal stromal tumors: the incidence, prevalence, clinical course, and prognostication in the preimatinib mesylate era - a population-based study in western Sweden. Cancer (2005) 103(4):821-9. doi:10.1002/cncr.20862

3. Agaimy A, Wunsch PH, Hofstaedter F, Blaszyk H, Rummele P, Gaumann A, et al. Minute gastric sclerosing stromal tumors (GIST tumorlets) are common in adults and frequently show c-KIT mutations. Am J Surg Pathol (2007) 31(1):113-20. doi:10.1097/01.pas.0000213307.05811.f0

4. Corless CL, McGreevey L, Haley A, Town A, Heinrich MC. KIT mutations are common in incidental gastrointestinal stromal tumors one centimeter or less in size. Am J Pathol (2002) 160(5):1567-72. doi:10.1016/S0002-9440(10)61103-0

5. Kawanowa K, Sakuma Y, Sakurai S, Hishima T, Iwasaki Y, Saito K, et al. High incidence of microscopic gastrointestinal stromal tumors in the stomach. Hum Pathol (2006) 37(12):1527-35. doi:10.1016/j.humpath.2006.07.002

6. Muenst S, Thies S, Went P, Tornillo L, Bihl MP, Dirnhofer S. Frequency, phenotype, and genotype of minute gastrointestinal stromal tumors in the stomach: an autopsy study. Hum Pathol (2011) 42(12):1849-54. doi:10.1016/j.humpath. 2011.01.024

7. Miettinen M, Lasota J. Gastrointestinal stromal tumors: pathology and prognosis at different sites. Semin Diagn Pathol (2006) 23(2):70-83. doi:10.1053/j. semdp.2006.09.001

8. Stout AP. Tumors of the stomach. Bull N Y Acad Med (1947) 23(2):101-8.

9. Stout AP. Bizarre smooth muscle tumors of the stomach. Cancer (1962) 15:400-9. doi:10.1002/1097-0142(196203/04)15:2<400::AIDCNCR2820150224>3.0.CO;2-P

10. Mazur MT, Clark HB. Gastric stromal tumors. Reappraisal of histogenesis. Am J Surg Pathol (1983) 7(6):507-19. doi:10.1097/00000478-198309000-00001

11. Miettinen M. Immunohistochemistry of soft tissue tumours - review with emphasis on 10 markers. Histopathology (2014) 64(1):101-18. doi:10.1111/ his. 12298

12. Robinson TL, Sircar K, Hewlett BR, Chorneyko K, Riddell RH, Huizinga JD. Gastrointestinal stromal tumors may originate from a subset of CD34-positive interstitial cells of Cajal. Am J Pathol (2000) 156(4):1157-63. doi:10.1016/ S0002-9440(10)64984-X

13. Hirota S, Isozaki K, Moriyama Y, Hashimoto K, Nishida T, Ishiguro S, et al. Gain-of-function mutations of c-KIT in human gastrointestinal stromal tumors. Science (1998) 279(5350):577-80. doi:10.1126/science.279.5350.577

14. Nakahara M, Isozaki K, Hirota S, Miyagawa J, Hase-Sawada N, Taniguchi M, et al. A novel gain-of-function mutation of c-KIT gene in gastrointestinal stromal tumors. Gastroenterology (1998) 115(5):1090-5. doi:10.1016/S00165085(98)70079-4

15. Kindblom LG, Remotti HE, Aldenborg F, Meis-Kindblom JM. Gastrointestinal pacemaker cell tumor (GIPACT): gastrointestinal stromal tumors show phenotypic characteristics of the interstitial cells of Cajal. Am J Pathol (1998) 152(5):1259-69.

16. Sarlomo-Rikala M, Kovatich AJ, Barusevicius A, Miettinen M. CD117: a sensitive marker for gastrointestinal stromal tumors that is more specific than CD34. Mod Pathol (1998) 11(8):728-34.
17. Huizinga JD, Thuneberg L, Kluppel M, Malysz J, Mikkelsen HB, Bernstein A. W/KIT gene required for interstitial cells of Cajal and for intestinal pacemaker activity. Nature (1995) 373(6512):347-9. doi:10.1038/373347a0

18. Hirota S, Ohashi A, Nishida T, Isozaki K, Kinoshita K, Shinomura Y, et al. Gain-of-function mutations of platelet-derived growth factor receptor alpha gene in gastrointestinal stromal tumors. Gastroenterology (2003) 125(3):660-7. doi:10.1016/S0016-5085(03)01046-1

19. Lasota J, Miettinen M. Clinical significance of oncogenic KIT and PDGFRA mutations in gastrointestinal stromal tumours. Histopathology (2008) 53(3):245-66. doi:10.1111/j.1365-2559.2008.02977.x

20. Agulnik M, Giel JL. Understanding rechallenge and resistance in the tyrosine kinase inhibitor era: imatinib in gastrointestinal stromal tumor. Am J Clin Oncol (2012) 37(4):417-22. doi:10.1097/COC.0b013e31824be3d6

21. Antonescu CR. The GIST paradigm: lessons for other kinase-driven cancers. J Pathol (2011) 223(2):251-61. doi:10.1002/path.2798

22. Joensuu H, Roberts PJ, Sarlomo-Rikala M, Andersson LC, Tervahartiala P, Tuveson D, et al. Effect of the tyrosine kinase inhibitor STI571 in a patient with a metastatic gastrointestinal stromal tumor. N Engl J Med (2001) 344(14):1052-6. doi:10.1056/NEJM200104053441404

23. Antonescu CR, Besmer P, Guo T, Arkun K, Hom G, Koryotowski B, et al. Acquired resistance to imatinib in gastrointestinal stromal tumor occurs through secondary gene mutation. Clin Cancer Res (2005) 11(11):4182-90. doi:10.1158/1078-0432.CCR-04-2245

24. Tornillo L. Biology of GISTs and mechanisms of imatinib resistance. Diagn Histopathol (2013) 19(6):203-10. doi:10.1016/j.mpdhp.2013.04.001

25. Agaimy A, Terracciano LM, Dirnhofer S, Tornillo L, Foerster A, Hartmann A, et al. V600E BRAF mutations are alternative early molecular events in a subset of KIT/PDGFRA wild-type gastrointestinal stromal tumours. J Clin Pathol (2009) 62(7):613-6. doi:10.1136/jcp.2009.064550

26. Miranda C, Nucifora M, Molinari F, Conca E, Anania MC, Bordoni A, et al. KRAS and BRAF mutations predict primary resistance to imatinib in gastrointestinal stromal tumors. Clin Cancer Res (2012) 18(6):1769-76. doi:10.1158/1078-0432.CCR-11-2230

27. Chi P, Chen Y, Zhang L, Guo X, Wongvipat J, Shamu T, et al. ETV1 is a lineage survival factor that cooperates with KIT in gastrointestinal stromal tumours. Nature (2010) 467(7317):849-53. doi:10.1038/nature09409

28. Hanks SK, Quinn AM, Hunter T. The protein kinase family: conserved features and deduced phylogeny of the catalytic domains. Science (1988) 241(4861):42-52. doi:10.1126/science.3291115

29. Corless CL, Barnett CM, Heinrich MC. Gastrointestinal stromal tumours: origin and molecular oncology. Nat Rev Cancer (2011) 11(12):865-78. doi:10. $1038 / \mathrm{nrc} 3143$

30. Duensing A, Medeiros F, McConarty B, Joseph NE, Panigrahy D, Singer S, et al. Mechanisms of oncogenic KIT signal transduction in primary gastrointestinal stromal tumors (GISTs). Oncogene (2004) 23(22):3999-4006. doi:10.1038/sj.onc. 1207525

31. Heinrich MC, Corless CL, Duensing A, McGreevey L, Chen CJ, Joseph N, et al. PDGFRA activating mutations in gastrointestinal stromal tumors. Science (2003) 299(5607):708-10. doi:10.1126/science.1079666

32. Kang HJ, Nam SW, Kim H, Rhee H, Kim NG, Kim H, et al. Correlation of KIT and platelet-derived growth factor receptor alpha mutations with gene activation and expression profiles in gastrointestinal stromal tumors. Oncogene (2005) 24(6):1066-74. doi:10.1038/sj.onc.1208358

33. Rossi F, Ehlers I, Agosti V, Socci ND, Viale A, Sommer G, et al. Oncogenic KIT signaling and therapeutic intervention in a mouse model of gastrointestinal stromal tumor. Proc Natl Acad Sci U S A (2006) 103(34):12843-8. doi:10.1073/pnas.0511076103

34. Rubin BP, Singer S, Tsao C, Duensing A, Lux ML, Ruiz R, et al. KIT activation is a ubiquitous feature of gastrointestinal stromal tumors. Cancer Res (2001) 61(22):8118-21.

35. Nishikawa S, Kusakabe M, Yoshinaga K, Ogawa M, Hayashi S, Kunisada T, et al. In utero manipulation of coat color formation by a monoclonal anti-c-KIT antibody: two distinct waves of c-KIT-dependency during melanocyte development. EMBO J (1991) 10(8):2111-8.

36. Curtin JA, Busam K, Pinkel D, Bastian BC. Somatic activation of KIT in distinct subtypes of melanoma. J Clin Oncol (2006) 24(26):4340-6. doi:10.1200/JCO. 2006.06.2984

37. Gari M, Goodeve A, Wilson G, Winship P, Langabeer S, Linch D, et al. c-KIT proto-oncogene exon 8 in-frame deletion plus insertion mutations in acute 
myeloid leukaemia. Br J Haematol (1999) 105(4):894-900. doi:10.1046/j.13652141.1999.01449.x

38. Nagata H, Worobec AS, Oh CK, Chowdhury BA, Tannenbaum S, Suzuki Y, et al. Identification of a point mutation in the catalytic domain of the protooncogene c-KIT in peripheral blood mononuclear cells of patients who have mastocytosis with an associated hematologic disorder. Proc Natl Acad Sci U S A (1995) 92(23):10560-4. doi:10.1073/pnas.92.23.10560

39. Tian Q, Frierson HF Jr, Krystal GW, Moskaluk CA. Activating c-KIT gene mutations in human germ cell tumors. Am J Pathol (1999) 154(6):1643-7. doi:10.1016/S0002-9440(10)65419-3

40. Mol CD, Dougan DR, Schneider TR, Skene RJ, Kraus ML, Scheibe DN, et al. Structural basis for the autoinhibition and STI-571 inhibition of c-KIT tyrosine kinase. J Biol Chem (2004) 279(30):31655-63. doi:10.1074/jbc.M403319200

41. Antonescu C. Gastrointestinal stromal tumors. Curr Top Microbiol Immunol (2012) 355:41-57. doi:10.1007/82_2011_161

42. Andersson J, Bumming P, Meis-Kindblom JM, Sihto H, Nupponen N, Joensuu $\mathrm{H}$, et al. Gastrointestinal stromal tumors with KIT exon 11 deletions are associated with poor prognosis. Gastroenterology (2006) 130(6):1573-81. doi:10.1053/j.gastro.2006.01.043

43. Martin J, Poveda A, Llombart-Bosch A, Ramos R, Lopez-Guerrero JA, Garcia del Muro J, et al. Deletions affecting codons 557-558 of the c-KIT gene indicate a poor prognosis in patients with completely resected gastrointestinal stromal tumors: a study by the Spanish Group for Sarcoma Research (GEIS). J Clin Oncol (2005) 23(25):6190-8. doi:10.1200/JCO.2005.19.554

44. Tzen CY, Mau BL. Analysis of CD117-negative gastrointestinal stromal tumors. World J Gastroenterol (2005) 11(7):1052-5.

45. Wardelmann E, Losen I, Hans V, Neidt I, Speidel N, Bierhoff E, et al. Deletion of Trp-557 and Lys-558 in the juxtamembrane domain of the c-KIT protooncogene is associated with metastatic behavior of gastrointestinal stromal tumors. Int J Cancer (2003) 106(6):887-95. doi:10.1002/ijc.11323

46. Antonescu CR, Sommer G, Sarran L, Tschernyavsky SJ, Riedel E, Woodruff JM, et al. Association of KIT exon 9 mutations with nongastric primary site and aggressive behavior: KIT mutation analysis and clinical correlates of 120 gastrointestinal stromal tumors. Clin Cancer Res (2003) 9(9):3329-37.

47. Lasota J, Dansonka-Mieszkowska A, Stachura T, Schneider-Stock R, Kallajoki $\mathrm{M}$, Steigen SE, et al. Gastrointestinal stromal tumors with internal tandem duplications in 3' end of KIT juxtamembrane domain occur predominantly in stomach and generally seem to have a favorable course. Mod Pathol (2003) 16(12):1257-64. doi:10.1097/01.MP.0000097365.72526.3E

48. Tornillo L, Terracciano LM. An update on molecular genetics of gastrointestinal stromal tumours. J Clin Pathol (2006) 59(6):557-63. doi:10.1136/jcp.2005. 031112

49. Lux ML, Rubin BP, Biase TL, Chen CJ, Maclure T, Demetri G, et al. KIT extracellular and kinase domain mutations in gastrointestinal stromal tumors. Am J Pathol (2000) 156(3):791-5. doi:10.1016/S0002-9440(10)64946-2

50. Antonescu CR, Viale A, Sarran L, Tschernyavsky SJ, Gonen M, Segal NH, et al. Gene expression in gastrointestinal stromal tumors is distinguished by KIT genotype and anatomic site. Clin Cancer Res (2004) 10(10):3282-90. doi:10.1158/1078-0432.CCR-03-0715

51. Battochio A, Mohammed S, Winthrop D, Lefresne S, Mulder K, Chu Q, et al. Detection of c-KIT and PDGFRA gene mutations in gastrointestinal stromal tumors: comparison of DHPLC and DNA sequencing methods using a single population-based cohort. Am J Clin Pathol (2010) 133(1):149-55.

52. Lasota J, Corless CL, Heinrich MC, Debiec-Rychter M, Sciot R, Wardelmann E, et al. Clinicopathologic profile of gastrointestinal stromal tumors (GISTs) with primary KIT exon 13 or exon 17 mutations: a multicenter study on 54 cases. Mod Pathol (2008) 21(4):476-84. doi:10.1038/modpathol.2008.2

53. Miettinen M, Makhlouf H, Sobin LH, Lasota J. Gastrointestinal stromal tumors of the jejunum and ileum: a clinicopathologic, immunohistochemical, and molecular genetic study of 906 cases before imatinib with long-term followup. Am J Surg Pathol (2006) 30(4):477-89. doi:10.1097/00000478-20060400000008

54. Cho S, Kitadai Y, Yoshida S, Tanaka S, Yoshihara M, Yoshida K, et al. Deletion of the KIT gene is associated with liver metastasis and poor prognosis in patients with gastrointestinal stromal tumor in the stomach. Int J Oncol (2006) 28(6):1361-7. doi:10.3892/ijo.28.6.1361

55. Kinoshita K, Isozaki K, Hirota S, Nishida T, Chen H, Nakahara M, et al. c-KIT gene mutation at exon 17 or 13 is very rare in sporadic gastrointestinal stromal tumors. J Gastroenterol Hepatol (2003) 18(2):147-51. doi:10.1046/j.1440- 1746. 2003.02911.x

56. Steigen SE, Eide TJ, Wasag B, Lasota J, Miettinen M. Mutations in gastrointestinal stromal tumors - a population-based study from Northern Norway. APMIS (2007) 115(4):289-98. doi:10.1111/j.1600-0463.2007.apm_587.x

57. Wardelmann E, Neidt I, Bierhoff E, Speidel N, Manegold C, Fischer HP, et al. c-KIT mutations in gastrointestinal stromal tumors occur preferentially in the spindle rather than in the epithelioid cell variant. Mod Pathol (2002) 15(2):125-36. doi:10.1038/modpathol.3880504

58. Agaram NP, Laquaglia MP, Ustun B, Guo T, Wong GC, Socci ND, et al. Molecular characterization of pediatric gastrointestinal stromal tumors. Clin Cancer Res (2008) 14(10):3204-15. doi:10.1158/1078-0432.CCR-07-1984

59. Debiec-Rychter M, Sciot R, Le Cesne A, Schlemmer M, Hohenberger P, van Oosterom AT, et al. KIT mutations and dose selection for imatinib in patients with advanced gastrointestinal stromal tumours. Eur J Cancer (2006) 42(8):1093-103. doi:10.1016/j.ejca.2006.01.030

60. Liegl B, Kepten I, Le C, Zhu M, Demetri GD, Heinrich MC, et al. Heterogeneity of kinase inhibitor resistance mechanisms in GIST. J Pathol (2008) 216(1):64-74. doi:10.1002/path.2382

61. Huss S, Kunstlinger H, Wardelmann E, Kleine MA, Binot E, Merkelbach-Bruse $\mathrm{S}$, et al. A subset of gastrointestinal stromal tumors previously regarded as wildtype tumors carries somatic activating mutations in KIT exon 8 (p.D419del). Mod Pathol (2013) 26(7):1004-12. doi:10.1038/modpathol.2013.47

62. Daniels M, Lurkin I, Pauli R, Erbstosser E, Hildebrandt U, Hellwig K, et al. Spectrum of KIT/PDGFRA/BRAF mutations and phosphatidylinositol-3-kinase pathway gene alterations in gastrointestinal stromal tumors (GIST). Cancer Lett (2011) 312(1):43-54. doi:10.1016/j.canlet.2011.07.029

63. Duensing A, Joseph NE, Medeiros F, Smith F, Hornick JL, Heinrich MC, et al. Protein kinase $\mathrm{C}$ theta (PKCtheta) expression and constitutive activation in gastrointestinal stromal tumors (GISTs). Cancer Res (2004) 64(15):5127-31. doi:10.1158/0008-5472.CAN-04-0559

64. Paner GP, Silberman S, Hartman G, Micetich KC, Aranha GV, Alkan S. Analysis of signal transducer and activator of transcription 3 (STAT3) in gastrointestinal stromal tumors. Anticancer Res (2003) 23(3B):2253-60.

65. Rubin BP, Antonescu CR, Scott-Browne JP, Comstock ML, Gu Y, Tanas MR, et al. A knock-in mouse model of gastrointestinal stromal tumor harboring KIT K641E. Cancer Res (2005) 65(15):6631-9. doi:10.1158/0008-5472.CAN05-0891

66. Zhu MJ, Ou WB, Fletcher CD, Cohen PS, Demetri GD, Fletcher JA. KIT oncoprotein interactions in gastrointestinal stromal tumors: therapeutic relevance. Oncogene (2007) 26(44):6386-95. doi:10.1038/sj.onc.1210464

67. Kuzu G, Keskin O, Gursoy A, Nussinov R. Constructing structural networks of signaling pathways on the proteome scale. Curr Opin Struct Biol (2012) 22(3):367-77. doi:10.1016/j.sbi.2012.04.004

68. De Luca A, Maiello MR, D’Alessio A, Pergameno M, Normanno N. The RAS/RAF/MEK/ERK and the PI3K/AKT signalling pathways: role in cancer pathogenesis and implications for therapeutic approaches. Expert Opin Ther Targets (2012) 16(Suppl 2):S17-27. doi:10.1517/14728222.2011. 639361

69. Johnston PA, Grandis JR. STAT3 signaling: anticancer strategies and challenges. Mol Interv (2011) 11(1):18-26. doi:10.1124/mi.11.1.4

70. Birner P, Beer A, Vinatzer U, Stary S, Hoftberger R, Nirtl N, et al. MAPKAP kinase 2 overexpression influences prognosis in gastrointestinal stromal tumors and associates with copy number variations on chromosome 1 and expression of p38 MAP kinase and ETV1. Clin Cancer Res (2012) 18(7):1879-87. doi:10.1158/1078-0432.CCR-11-2364

71. Zhang Y, Gu ML, Zhou XX, Ma H, Yao HP, Ji F. Altered expression of ETV1 and its contribution to tumorigenic phenotypes in gastrointestinal stromal tumors. Oncol Rep (2014) 32(3):927-34. doi:10.3892/or.2014.3281

72. Bauer S, Yu LK, Demetri GD, Fletcher JA. Heat shock protein 90 inhibition in imatinib-resistant gastrointestinal stromal tumor. Cancer Res (2006) 66(18):9153-61. doi:10.1158/0008-5472.CAN-06-0165

73. Fumo G, Akin C, Metcalfe DD, Neckers L. 17-Allylamino-17demethoxygeldanamycin (17-AAG) is effective in down-regulating mutated, constitutively activated KIT protein in human mast cells. Blood (2004) 103(3):1078-84. doi:10.1182/blood-2003-07-2477

74. Smyth T, Van Looy T, Curry JE, Rodriguez-Lopez AM, Wozniak A, Zhu M, et al. The HSP90 inhibitor, AT13387, is effective against imatinib-sensitive 
and -resistant gastrointestinal stromal tumor models. Mol Cancer Ther (2012) 11(8):1799-808. doi:10.1158/1535-7163.MCT-11-1046

75. Pauls K, Merkelbach-Bruse S, Thal D, Buttner R, Wardelmann E. PDGFRalphaand c-KIT-mutated gastrointestinal stromal tumours (GISTs) are characterized by distinctive histological and immunohistochemical features. Histopathology (2005) 46(2):166-75. doi:10.1111/j.1365-2559.2005.02061.x

76. Miettinen M, Furlong M, Sarlomo-Rikala M, Burke A, Sobin LH, Lasota J. Gastrointestinal stromal tumors, intramural leiomyomas, and leiomyosarcomas in the rectum and anus: a clinicopathologic, immunohistochemical, and molecular genetic study of 144 cases. Am J Surg Pathol (2001) 25(9):1121-33. doi:10.1097/00000478-200111000-00013

77. Miettinen M, Kopczynski J, Makhlouf HR, Sarlomo-Rikala M, Gyorffy H, Burke A, et al. Gastrointestinal stromal tumors, intramural leiomyomas, and leiomyosarcomas in the duodenum: a clinicopathologic, immunohistochemical, and molecular genetic study of 167 cases. Am J Surg Pathol (2003) 27(5):625-41. doi:10.1097/00000478-200305000-00006

78. Miettinen M, Sarlomo-Rikala M, Sobin LH, Lasota J. Gastrointestinal stromal tumors and leiomyosarcomas in the colon: a clinicopathologic, immunohistochemical, and molecular genetic study of 44 cases. Am J Surg Pathol (2000) 24(10):1339-52. doi:10.1097/00000478-200010000-00003

79. Penzel R, Aulmann S, Moock M, Schwarzbach M, Rieker RJ, Mechtersheimer G. The location of KIT and PDGFRA gene mutations in gastrointestinal stromal tumours is site and phenotype associated. J Clin Pathol (2005) 58(6):634-9. doi:10.1136/jcp.2004.021766

80. Lasota J, Dansonka-Mieszkowska A, Sobin LH, Miettinen M. A great majority of GISTs with PDGFRA mutations represent gastric tumors of low or no malignant potential. Lab Invest (2004) 84(7):874-83. doi:10.1038/labinvest.3700122

81. Lasota J, Stachura J, Miettinen M. GISTs with PDGFRA exon 14 mutations represent subset of clinically favorable gastric tumors with epithelioid morphology. Lab Invest (2006) 86(1):94-100. doi:10.1038/labinvest.3700360

82. Wardelmann E, Hrychyk A, Merkelbach-Bruse S, Pauls K, Goldstein J, Hohenberger $\mathrm{P}$, et al. Association of platelet-derived growth factor receptor alpha mutations with gastric primary site and epithelioid or mixed cell morphology in gastrointestinal stromal tumors. J Mol Diagn (2004) 6(3):197-204. doi:10.1016/S1525-1578(10)60510-7

83. Subramanian S, West RB, Corless CL, Ou W, Rubin BP, Chu KM, et al. Gastrointestinal stromal tumors (GISTs) with KIT and PDGFRA mutations have distinct gene expression profiles. Oncogene (2004) 23(47):7780-90. doi:10.1038/sj.onc.1208056

84. Debiec-Rychter M, Wasag B, Stul M, De Wever I, Van Oosterom A, Hagemeijer A, et al. Gastrointestinal stromal tumours (GISTs) negative for KIT (CD117 antigen) immunoreactivity. J Pathol (2004) 202(4):430-8. doi:10.1002/path. 1546

85. Matei D, Satpathy M, Cao L, Lai YC, Nakshatri H, Donner DB. The plateletderived growth factor receptor alpha is destabilized by geldanamycins in cancer cells. J Biol Chem (2007) 282(1):445-53. doi:10.1074/jbc.M607012200

86. Miettinen M, Wang ZF, Lasota J. DOG1 antibody in the differential diagnosis of gastrointestinal stromal tumors: a study of 1840 cases. Am J Surg Pathol (2009) 33(9):1401-8. doi:10.1097/PAS.0b013e3181a90ela

87. Wozniak A, Sciot R, Guillou L, Pauwels P, Wasag B, Stul M, et al. Array CGH analysis in primary gastrointestinal stromal tumors: cytogenetic profile correlates with anatomic site and tumor aggressiveness, irrespective of mutational status. Genes Chromosomes Cancer (2007) 46(3):261-76. doi:10.1002/ gcc. 20408

88. Corless CL, Schroeder A, Griffith D, Town A, McGreevey L, Harrell P, et al. PDGFRA mutations in gastrointestinal stromal tumors: frequency, spectrum and in vitro sensitivity to imatinib. J Clin Oncol (2005) 23(23):5357-64. doi:10.1200/JCO.2005.14.068

89. Daum O, Grossmann P, Vanecek T, Sima R, Mukensnabl P, Michal M. Diagnostic morphological features of PDGFRA-mutated gastrointestinal stromal tumors: molecular genetic and histologic analysis of 60 cases of gastric gastrointestinal stromal tumors. Ann Diagn Pathol (2007) 11(1):27-33. doi:10.1016/j.anndiagpath.2006.10.002

90. Haller F, Happel N, Schulten HJ, von Heydebreck A, Schwager S, Armbrust T, et al. Site-dependent differential KIT and PDGFRA expression in gastric and intestinal gastrointestinal stromal tumors. Mod Pathol (2007) 20(10):1103-11. doi:10.1038/modpathol.3800947
91. Heinrich MC, Corless CL, Demetri GD, Blanke CD, von Mehren M, Joensuu $\mathrm{H}$, et al. Kinase mutations and imatinib response in patients with metastatic gastrointestinal stromal tumor. J Clin Oncol (2003) 21(23):4342-9. doi:10.1200/JCO.2003.04.190

92. Holden JA, Willmore-Payne C, Coppola D, Garrett CR, Layfield LJ. Highresolution melting amplicon analysis as a method to detect c-KIT and plateletderived growth factor receptor alpha activating mutations in gastrointestinal stromal tumors. Am J Clin Pathol (2007) 128(2):230-8. doi:10.1309/ 7TEH56K6WWXENNQY

93. Medeiros F, Corless CL, Duensing A, Hornick JL, Oliveira AM, Heinrich MC, et al. KIT-negative gastrointestinal stromal tumors: proof of concept and therapeutic implications. Am J Surg Pathol (2004) 28(7):889-94. doi:10.1097/ 00000478-200407000-00007

94. Sakurai S, Hasegawa T, Sakuma Y, Takazawa Y, Motegi A, Nakajima T, et al. Myxoid epithelioid gastrointestinal stromal tumor (GIST) with mast cell infiltrations: a subtype of GIST with mutations of platelet-derived growth factor receptor alpha gene. Hum Pathol (2004) 35(10):1223-30. doi:10.1016/j. humpath.2004.07.008

95. Wasag B, Debiec-Rychter M, Pauwels P, Stul M, Vranckx H, Oosterom AV, et al. Differential expression of KIT/PDGFRA mutant isoforms in epithelioid and mixed variants of gastrointestinal stromal tumors depends predominantly on the tumor site. Mod Pathol (2004) 17(8):889-94. doi:10.1038/modpathol. 3800136

96. Hostein I, Faur N, Primois C, Boury F, Denard J, Emile JF, et al. BRAF mutation status in gastrointestinal stromal tumors. Am J Clin Pathol (2010) 133(1):141-8. doi:10.1309/AJCPPCKGA2QGBJ1R

97. Lasota J, Xi L, Coates T, Dennis R, Evbuomwan MO, Wang ZF, et al. No KRAS mutations found in gastrointestinal stromal tumors (GISTs): molecular genetic study of 514 cases. Mod Pathol (2013) 26(11):1488-91. doi:10.1038/ modpathol.2013.89

98. Ward BA, Gutmann DH. Neurofibromatosis 1: from lab bench to clinic. Pediatr Neurol (2005) 32(4):221-8. doi:10.1016/j.pediatrneurol.2004.11.002

99. Nannini M, Biasco G, Astolfi A, Pantaleo MA. An overview on molecular biology of KIT/PDGFRA wild type (WT) gastrointestinal stromal tumours (GIST). J Med Genet (2013) 50(10):653-61. doi:10.1136/jmedgenet-2013-101695

100. Kinoshita K, Hirota S, Isozaki K, Ohashi A, Nishida T, Kitamura Y, et al. Absence of c-KIT gene mutations in gastrointestinal stromal tumours from neurofibromatosis type 1 patients. J Pathol (2004) 202(1):80-5. doi:10.1002/path.1487

101. Miettinen M, Fetsch JF, Sobin LH, Lasota J. Gastrointestinal stromal tumors in patients with neurofibromatosis 1: a clinicopathologic and molecular genetic study of 45 cases. Am J Surg Pathol (2006) 30(1):90-6. doi:10.1097/01.pas. 0000176433.81079.bd

102. Nemoto H, Tate G, Schirinzi A, Suzuki T, Sasaya S, Yoshizawa Y, et al. Novel NF1 gene mutation in a Japanese patient with neurofibromatosis type 1 and a gastrointestinal stromal tumor. J Gastroenterol (2006) 41(4):378-82. doi:10.1007/s00535-006-1772-7

103. Takazawa Y, Sakurai S, Sakuma Y, Ikeda T, Yamaguchi J, Hashizume Y, et al. Gastrointestinal stromal tumors of neurofibromatosis type I (von Recklinghausen's disease). Am J Surg Pathol (2005) 29(6):755-63. doi:10.1097/01.pas. 0000163359.32734.f9

104. Yantiss RK, Rosenberg AE, Sarran L, Besmer P, Antonescu CR. Multiple gastrointestinal stromal tumors in type I neurofibromatosis: a pathologic and molecular study. Mod Pathol (2005) 18(4):475-84. doi:10.1038/modpathol. 3800334

105. Maertens O, Prenen H, Debiec-Rychter M, Wozniak A, Sciot R, Pauwels P, et al. Molecular pathogenesis of multiple gastrointestinal stromal tumors in NF1 patients. Hum Mol Genet (2006) 15(6):1015-23. doi:10.1093/hmg/ddl016

106. Rutter J, Winge DR, Schiffman JD. Succinate dehydrogenase - assembly, regulation and role in human disease. Mitochondrion (2010) 10(4):393-401. doi:10.1016/j.mito.2010.03.001

107. Barletta JA, Hornick JL. Succinate dehydrogenase-deficient tumors: diagnostic advances and clinical implications. Adv Anat Pathol (2012) 19(4):193-203. doi:10.1097/PAP.0b013e31825c6bc6

108. Gill AJ. Succinate dehydrogenase (SDH) and mitochondrial driven neoplasia. Pathology (2012) 44(4):285-92. doi:10.1097/PAT.0b013e3283539932

109. Janeway KA, Kim SY, Lodish M, Nose V, Rustin P, Gaal J, et al. Defects in succinate dehydrogenase in gastrointestinal stromal tumors lacking KIT 
and PDGFRA mutations. Proc Natl Acad Sci U S A (2011) 108(1):314-8. doi:10.1073/pnas.1009199108

110. Miettinen M, Wang ZF, Sarlomo-Rikala M, Osuch C, Rutkowski P, Lasota J. Succinate dehydrogenase-deficient GISTs: a clinicopathologic, immunohistochemical, and molecular genetic study of 66 gastric GISTs with predilection to young age. Am J Surg Pathol (2011) 35(11):1712-21. doi:10.1097/PAS. 0b013e3182260752

111. Chou A, Chen J, Clarkson A, Samra JS, Clifton-Bligh RJ, Hugh TJ, et al. Succinate dehydrogenase-deficient GISTs are characterized by IGF1R overexpression. Mod Pathol (2012) 25(9):1307-13. doi:10.1038/modpathol.2012.77

112. Doyle LA, Nelson D, Heinrich MC, Corless CL, Hornick JL. Loss of succinate dehydrogenase subunit B (SDHB) expression is limited to a distinctive subset of gastric wild-type gastrointestinal stromal tumours: a comprehensive genotype-phenotype correlation study. Histopathology (2012) 61(5):801-9. doi:10.1111/j.1365-2559.2012.04300.x

113. Gaal J, Stratakis CA, Carney JA, Ball ER, Korpershoek E, Lodish MB, et al. SDHB immunohistochemistry: a useful tool in the diagnosis of Carney-Stratakis and Carney triad gastrointestinal stromal tumors. Mod Pathol (2011) 24(1):147-51. doi:10.1038/modpathol.2010.185

114. Gill AJ, Chou A, Vilain R, Clarkson A, Lui M, Jin R, et al. Immunohistochemistry for SDHB divides gastrointestinal stromal tumors (GISTs) into 2 distinct types. Am J Surg Pathol (2010) 34(5):636-44. doi:10.1097/PAS.0b013e3181d6150d

115. Gill AJ, Chou A, Vilain RE, Clifton-Bligh RJ. "Pediatric-type" gastrointestinal stromal tumors are SDHB negative ("type 2") GISTs. Am J Surg Pathol (2011) 35(8):1245-7; author reply 7-8. doi:10.1097/PAS.0b013e3182217b93

116. Rege TA, Wagner AJ, Corless CL, Heinrich MC, Hornick JL. "Pediatrictype" gastrointestinal stromal tumors in adults: distinctive histology predicts genotype and clinical behavior. Am J Surg Pathol (2011) 35(4):495-504. doi:10.1097/PAS.0b013e31820e5f7d

117. Carney JA, Stratakis CA. Familial paraganglioma and gastric stromal sarcoma: a new syndrome distinct from the Carney triad. Am J Med Genet (2002) 108(2):132-9. doi:10.1002/ajmg.10235

118. Italiano A, Chen CL, Sung YS, Singer S, DeMatteo RP, LaQuaglia MP, et al. SDHA loss of function mutations in a subset of young adult wild-type gastrointestinal stromal tumors. BMC Cancer (2012) 12:408. doi:10.1186/14712407-12-408

119. Wardelmann E. Translational research and diagnosis in GIST. Pathologe (2012) 33(Suppl 2):273-7. doi:10.1007/s00292-012-1682-9

120. Miettinen M, Lasota J. Succinate dehydrogenase deficient gastrointestinal stromal tumors (GISTs) - A review. Int J Biochem Cell Biol (2014) 53:514-9. doi:10.1016/j.biocel.2014.05.033

121. Briere JJ, Favier J, Benit P, El Ghouzzi V, Lorenzato A, Rabier D, et al. Mitochondrial succinate is instrumental for HIFlalpha nuclear translocation in SDHA-mutant fibroblasts under normoxic conditions. Hum Mol Genet (2005) 14(21):3263-9. doi:10.1093/hmg/ddi359

122. Selak MA, Armour SM, MacKenzie ED, Boulahbel H, Watson DG, Mansfield $\mathrm{KD}$, et al. Succinate links TCA cycle dysfunction to oncogenesis by inhibiting HIF-alpha prolyl hydroxylase. Cancer Cell (2005) 7(1):77-85. doi:10.1016/j. ccr.2004.11.022

123. Lasota J, Wang Z, Kim SY, Helman L, Miettinen M. Expression of the receptor for type I insulin-like growth factor (IGF1R) in gastrointestinal stromal tumors: an immunohistochemical study of 1078 cases with diagnostic and therapeutic implications. Am J Surg Pathol (2013) 37(1):114-9. doi:10.1097/PAS.0b013e3182613c86

124. Beadling C, Patterson J, Justusson E, Nelson D, Pantaleo MA, Hornick JL, et al. Gene expression of the IGF pathway family distinguishes subsets of gastrointestinal stromal tumors wild type for KIT and PDGFRA. Cancer Med (2013) 2(1):21-31. doi:10.1002/cam4.57

125. Rikhof B, van der Graaf WT, Suurmeijer AJ, van Doorn J, Meersma GJ, Groenen PJ, et al. "Big"-insulin-like growth factor-II signaling is an autocrine survival pathway in gastrointestinal stromal tumors. Am J Pathol (2012) 181(1):303-12. doi:10.1016/j.ajpath.2012.03.028

126. Breiner JA, Meis-Kindblom J, Kindblom LG, McComb E, Liu J, Nelson M, et al. Loss of $14 \mathrm{q}$ and $22 \mathrm{q}$ in gastrointestinal stromal tumors (pacemaker cell tumors). Cancer Genet Cytogenet (2000) 120(2):111-6. doi:10.1016/S01654608(00)00212-0

127. Derre J, Lagace R, Terrier P, Sastre X, Aurias A. Consistent DNA losses on the short arm of chromosome 1 in a series of malignant gastrointestinal stromal tumors. Cancer Genet Cytogenet (2001) 127(1):30-3. doi:10.1016/ S0165-4608(00)00409-X

128. El-Rifai W, Sarlomo-Rikala M, Andersson LC, Knuutila S, Miettinen M. DNA sequence copy number changes in gastrointestinal stromal tumors: tumor progression and prognostic significance. Cancer Res (2000) 60(14):3899-903.

129. Gunawan B, von Heydebreck A, Sander B, Schulten HJ, Haller F, Langer C, et al. An oncogenetic tree model in gastrointestinal stromal tumours (GISTs) identifies different pathways of cytogenetic evolution with prognostic implications. J Pathol (2007) 211(4):463-70. doi:10.1002/path.2128

130. Ylipaa A, Hunt KK, Yang J, Lazar AJ, Torres KE, Lev DC, et al. Integrative genomic characterization and a genomic staging system for gastrointestinal stromal tumors. Cancer (2011) 117(2):380-9. doi:10.1002/cncr.25594

131. Tornillo L, Duchini G, Carafa V, Lugli A, Dirnhofer S, Di Vizio D, et al. Patterns of gene amplification in gastrointestinal stromal tumors (GIST). Lab Invest (2005) 85(7):921-31. doi:10.1038/labinvest.3700284

132. Perrone F, Tamborini E, Dagrada GP, Colombo F, Bonadiman L, Albertini V, et al. 9p21 locus analysis in high-risk gastrointestinal stromal tumors characterized for c-KIT and platelet-derived growth factor receptor alpha gene alterations. Cancer (2005) 104(1):159-69. doi:10.1002/cncr.21113

133. Schneider-Stock R, Boltze C, Lasota J, Miettinen M, Peters B, Pross M, et al. High prognostic value of p16INK4 alterations in gastrointestinal stromal tumors. $J$ Clin Oncol (2003) 21(9):1688-97. doi:10.1200/JCO.2003.08.101

134. Schneider-Stock R, Boltze C, Lasota J, Peters B, Corless CL, Ruemmele P, et al. Loss of p16 protein defines high-risk patients with gastrointestinal stromal tumors: a tissue microarray study. Clin Cancer Res (2005) 11(2 Pt 1):638-45.

135. Haller F, Lobke C, Ruschhaupt M, Cameron S, Schulten HJ, Schwager S, et al. Loss of 9p leads to p16INK4A down-regulation and enables RB/E2F1dependent cell cycle promotion in gastrointestinal stromal tumours (GISTs). J Pathol (2008) 215(3):253-62. doi:10.1002/path.2352

136. Dematteo RP, Heinrich MC, El-Rifai WM, Demetri G. Clinical management of gastrointestinal stromal tumors: before and after STI-571. Hum Pathol (2002) 33(5):466-77. doi:10.1053/hupa.2002.124122

137. Heinrich MC, Maki RG, Corless CL, Antonescu CR, Harlow A, Griffith D, et al. Primary and secondary kinase genotypes correlate with the biological and clinical activity of sunitinib in imatinib-resistant gastrointestinal stromal tumor. $J$ Clin Oncol (2008) 26(33):5352-9. doi:10.1200/JCO.2007.15.7461

138. Montemurro M, Bauer S. Treatment of gastrointestinal stromal tumor after imatinib and sunitinib. Curr Opin Oncol (2011) 23(4):367-72. doi:10.1097/ CCO.0b013e3283477ac2

139. Gupta A, Roy S, Lazar AJ, Wang WL, McAuliffe JC, Reynoso D, et al. Autophagy inhibition and antimalarials promote cell death in gastrointestinal stromal tumor (GIST). Proc Natl Acad Sci U S A (2010) 107(32):14333-8. doi:10.1073/pnas.1000248107

140. Le Cesne A, Ray-Coquard I, Bui BN, Adenis A, Rios M, Bertucci F, et al. Discontinuation of imatinib in patients with advanced gastrointestinal stromal tumours after 3 years of treatment: an open-label multicentre randomised phase 3 trial. Lancet Oncol (2010) 11(10):942-9. doi:10.1016/S1470-2045(10) 70222-9

141. Casali PG. Successes and limitations of targeted cancer therapy in gastrointestinal stromal tumors. Prog Tumor Res (2014) 41:51-61. doi:10.1159/000355898

142. Heinrich MC, Corless CL, Blanke CD, Demetri GD, Joensuu H, Roberts PJ, et al. Molecular correlates of imatinib resistance in gastrointestinal stromal tumors. J Clin Oncol (2006) 24(29):4764-74. doi:10.1200/JCO.2006.06.2265

143. Gounder MM, Maki RG. Molecular basis for primary and secondary tyrosine kinase inhibitor resistance in gastrointestinal stromal tumor. Cancer Chemother Pharmacol (2011) 67(Suppl 1):S25-43. doi:10.1007/s00280-010-1526-3

144. Weisberg E, Wright RD, Jiang J, Ray A, Moreno D, Manley PW, et al. Effects of PKC412, nilotinib, and imatinib against GIST-associated PDGFRA mutants with differential imatinib sensitivity. Gastroenterology (2006) 131(6):1734-42. doi:10.1053/j.gastro.2006.09.017

145. Choi H, Charnsangavej C, Faria SC, Macapinlac HA, Burgess MA, Patel SR, et al. Correlation of computed tomography and positron emission tomography in patients with metastatic gastrointestinal stromal tumor treated at a single institution with imatinib mesylate: proposal of new computed tomography response criteria. J Clin Oncol (2007) 25(13):1753-9. doi:10.1200/JCO.2006. 07.3049

146. Grimpen F, Yip D, McArthur G, Waring P, Goldstein D, Loughrey M, et al. Resistance to imatinib, low-grade FDG-avidity on PET, and acquired KIT exon 17 
mutation in gastrointestinal stromal tumour. Lancet Oncol (2005) 6(9):724-7. doi:10.1016/S1470-2045(05)70321-1

147. Koyama T, Nimura H, Kobayashi K, Marushima H, Odaira H, Kashimura H, et al. Recurrent gastrointestinal stromal tumor (GIST) of the stomach associated with a novel c-KIT mutation after imatinib treatment. Gastric Cancer (2006) 9(3):235-9. doi:10.1007/s10120-006-0368-5

148. Wakai T, Kanda T, Hirota S, Ohashi A, Shirai Y, Hatakeyama K. Late resistance to imatinib therapy in a metastatic gastrointestinal stromal tumour is associated with a second KIT mutation. Br J Cancer (2004) 90(11): 2059-61. doi:10.1038/sj.bjc.6601819

149. Roskoski R Jr. Structure and regulation of KIT protein-tyrosine kinase - the stem cell factor receptor. Biochem Biophys Res Commun (2005) 338(3):1307-15. doi:10.1016/j.bbrc.2005.09.150

150. Desai J, Shankar S, Heinrich MC, Fletcher JA, Fletcher CD, Manola J, et al. Clonal evolution of resistance to imatinib in patients with metastatic gastrointestinal stromal tumors. Clin Cancer Res (2007) 13(18 Pt 1):5398-405. doi:10.1158/1078-0432.CCR-06-0858

151. Miselli FC, Casieri P, Negri T, Orsenigo M, Lagonigro MS, Gronchi A, et al. c-KIT/PDGFRA gene status alterations possibly related to primary imatinib resistance in gastrointestinal stromal tumors. Clin Cancer Res (2007) 13(8):2369-77. doi:10.1158/1078-0432.CCR-06-1745

152. Bauer S, Duensing A, Demetri GD, Fletcher JA. KIT oncogenic signaling mechanisms in imatinib-resistant gastrointestinal stromal tumor: PI3kinase/AKT is a crucial survival pathway. Oncogene (2007) 26(54):7560-8. doi:10.1038/sj.onc. 1210558
153. Tarn C, Rink L, Merkel E, Flieder D, Pathak H, Koumbi D, et al. Insulinlike growth factor 1 receptor is a potential therapeutic target for gastrointestinal stromal tumors. Proc Natl Acad Sci U S A (2008) 105(24):8387-92. doi:10.1073/pnas.0803383105

154. Mahadevan D, Sutton GR, Arteta-Bulos R, Bowden CJ, Miller PJ, Swart RE, et al. Phase $1 \mathrm{~b}$ study of safety, tolerability and efficacy of R1507, a monoclonal antibody to IGF-1R in combination with multiple standard oncology regimens in patients with advanced solid malignancies. Cancer Chemother Pharmacol (2014) 73(3):467-73. doi:10.1007/s00280-013-2372-x

Conflict of Interest Statement: The author declares that the research was conducted in the absence of any commercial or financial relationships that could be construed as a potential conflict of interest.

Received: 19 August 2014; accepted: 17 October 2014; published online: 11 November 2014.

Citation: Tornillo L (2014) Gastrointestinal stromal tumor - an evolving concept. Front. Med. 1:43. doi: 10.3389/fmed.2014.00043

This article was submitted to Pathology, a section of the journal Frontiers in Medicine. Copyright (c) 2014 Tornillo. This is an open-access article distributed under the terms of the Creative Commons Attribution License (CC BY). The use, distribution or reproduction in other forums is permitted, provided the original author(s) or licensor are credited and that the original publication in this journal is cited, in accordance with accepted academic practice. No use, distribution or reproduction is permitted which does not comply with these terms. 